\title{
THE JAUNDICED EYE AS A SOURCE OF DONOR MATERIAL* $\dagger$
}

\author{
BY
}

\author{
R. R. TOEWS AND P. K. BASU
}

From the Department of Ophthalmology, Faculty of Medicine, University of Toronto

AT the present time jaundiced eyes are frequently rejected as sources of donor material for corneal grafting or for vitreous implantation. One reason for not using these eyes is their discoloration (Edwards and Locke, 1960). This investigation was undertaken in the hope that adequate reasons for or against the use of jaundiced eyes would be discovered. The bilirubin content of the ocular fluids and tissues of jaundiced and non-jaundiced subjects was measured, and that of the ocular fluids of jaundiced and non-jaundiced albino rabbits was also determined.

\section{Methods and Material}

(A) Studies on Human Material.-Eight pairs of human donor eyes were obtained from the Eye Bank of Canada (Ontario Division). Six of the donors were suffering at death from obstructive jaundice and two had had no history of jaundice. All of these eyes were enucleated within a few hours of death. The data on the serum bilirubin levels were obtained from hospital records. The methods of bilirubin determination used in this hospital were employed throughout the present investigation (Malloy and Evelyn, 1937; Carter and McGann, 1959).

Aqueous samples were aspirated with a fine needle from the donor eyes, one having a high and the other a low concentration of bilirubin in the serum. Vitreous samples were aspirated with a large-bore needle from all the jaundiced and nonjaundiced eyes. Two pairs of corneae from patients with very high levels of serum bilirubin were removed by dissection. Each pair was weighed and then placed in $10 \mathrm{ml}$. of distilled water in order to extract the direct bilirubin from the tissues. After 72 hours the resultant solution was concentrated by freeze-drying and then reconstituted in $2 \mathrm{ml}$. distilled water.

(B) Studies on Rabbits.-Two adult albino rabbits were subjected to complete division and ligation of the common bile duct in order to produce obstructive jaundice; 6 weeks later serum samples were collected, the animals were killed, and the eyes were enucleated. Aqueous and vitreous samples were taken from the eyes for determination of normal bilirubin levels.

Identical methods were used with both human and rabbit material for the determination of the total bilirubin in serum, aqueous, vitreous, and corneal extracts.

* Received for publication October 2, 1961.

† This study was supported by a Public Health Research Grant. 
This method was found to be only roughly accurate for levels below $0.5 \mathrm{mg}$. per cent. but more satisfactory above this level. However, the method sufficed to illustrate the great difference between the serum and ocular concentrations of bilirubin.

\section{Results}

The results are shown in Tables I and II. The important point to be observed is the wide difference between the bilirubin levels in the serum jaundiced individuals and in the ocular fluids and corneae from their jaundiced eyes.

TABLE I

TOTAL BILIRUBIN CONCENTRATION IN SERUM, AQUEOUS, VITREOUS, AND CORNEA OF JAUNDICED AND NON-JAUNDICED HUMAN SUBJECTS

\begin{tabular}{|c|c|c|c|c|}
\hline \multirow{2}{*}{$\begin{array}{c}\text { Type of } \\
\text { Human Donor }\end{array}$} & \multicolumn{4}{|c|}{ Bilirubin Concentration (mg. per cent.) } \\
\hline & Serum & Aqueous & Vitreous & Cornea \\
\hline $\begin{array}{c}\text { Jaundiced } \\
1 \\
2 \\
3 \\
4 \\
5 \\
6\end{array}$ & $\begin{array}{c}2 \cdot 0 \\
5 \cdot 0 \\
6 \cdot 6 \\
35 \cdot 0 \\
37 \cdot 0 \\
4 \cdot 75\end{array}$ & $\begin{array}{l}0.1 \\
0.2\end{array}$ & $\begin{array}{l}0.4 \\
0.25 \\
0.6 \\
0.0 \\
0.4 \\
0.25\end{array}$ & $\begin{array}{l}1.9 \\
\\
1.9 \\
0.75\end{array}$ \\
\hline $\begin{array}{c}\text { Non-Jaundiced } \\
\mathbf{1} \\
\mathbf{2}\end{array}$ & $\begin{array}{l}0.3 \\
0.5\end{array}$ & & $\begin{array}{l}0.0 \\
0.0\end{array}$ & \\
\hline
\end{tabular}

TABLE II

TOTAL BILIRUBIN CONCENTRATION IN THE SERUM, AQUEOUS, AND VITREOUS OF JAUNDICED AND NORMAL RABBITS

\begin{tabular}{c|c|c|c}
\hline \multirow{2}{*}{ Type of Rabbit } & \multicolumn{2}{|c}{ Bilirubin Concentration (mg. per cent.) } \\
\cline { 2 - 4 } & Serum & Aqueous & Vitreous \\
\hline $\begin{array}{c}\text { Jaundiced } \\
\frac{1}{2}\end{array}$ & $\begin{array}{c}8.5 \\
8.8\end{array}$ & 0.5 & $\begin{array}{l}0.3 \\
0.0\end{array}$ \\
\hline $\begin{array}{c}\text { Normal } \\
1\end{array}$ & 0.5 & 0.5 & 0.5 \\
\hline
\end{tabular}

Table I shows that the total bilirubin levels of the sera from the jaundiced patients ranged from 2 to $37 \mathrm{mg}$. per cent., whereas the aqueous and vitreous bilirubin levels were all below $0.6 \mathrm{mg}$. per cent. The corneae from Patients 
4 and 5 contained less than $2 \mathrm{mg}$. direct bilirubin per $100 \mathrm{~g}$. tissue, even though the serum bilirubin levels were very high. Similarly, in Table II the total bilirubin levels of the sera from the two jaundiced rabbits were 8.5 and $8.8 \mathrm{mg}$. per cent. and the levels in the vitreous and aqueous were $0.5 \mathrm{mg}$. per cent. or less.

In the course of the experiment several observations pointed to the ready solubility of direct bilirubin. A jaundiced eye set on a gauze square soon imparted some of its yellow colour to the gauze, and distilled water was quickly tinted yellow when jaundiced tissue was placed in it. Attempts to study the bilirubin distribution in tissues were unsuccessful, apparently because the fluids used in fixation and staining washed the bilirubin out of the tissues. It was also noted that fluids which appeared quite yellow on gross examination could contain very low concentrations of bilirubin.

\section{Discussion}

The values obtained indicate that only small amounts of bilirubin enter the ocular fluids and corneae, even when the serum bilirubin levels were very high. This result agrees with the findings of Naumann and Young (1960) that the average bilirubin concentration of vitreous was 220 times less than that of serum in 43 patients who were jaundiced at the time of autopsy. There appears to be a barrier to bilirubin between the blood and the ocular tissues and fluids. This may be analogous to the blood-brain barrier which has been the subject of considerable investigation (Cantarow and Trumper, 1955; Robbins, 1957). The spinal fluid bilirubin concentration in jaundice is usually between one-tenth and one-hundredth of that of the serum (Berman, Lapham, Pastore, 1954). Naumann and Young (1960) found the spinal fluid level to be 35 times less than the serum level.

It seems probable that the amount of bilirubin present in jaundiced eyes is too small to have any significant damaging effect on the tissues and that the yellow discolouration should not preclude the use of these eyes. The patients and rabbits used in this study were suffering from obstructive jaundice due to blockage of the bile ducts; in such cases the predominant serum pigment is direct bilirubin, which has been processed by the liver and then regurgitated into the circulation (Cantarow and Trumper, 1955). Direct bilirubin is partly defined by its water solubility (Robbins, 1957). Yellow fluid was observed to escape from the tissues of jaundiced eyes during the investigation, and this suggests that the irrigation of a donor cornea might further decrease its bilirubin content. Furthermore, the small amount of bilirubin in the jaundiced cornea or vitreous would probably be quickly disposed of by the blood and fluid circulation of the recipient eye.

It is evident that other factors apart from their bilirubin content may render jaundiced tissues unsuitable for transplantation. Duke-Elder (1940) summarized the older literature in which several authors related jaundice and 
liver disease to degenerations of the ocular tissues (Hartshorne, 1934). In obstructive jaundice vitamin A deficiency can damage the conjunctiva, cornea, and retina (Duncan, 1959). In Wilson's disease the cornea, liver, and brain are all affected by the metabolic defect (Sherlock, 1958). The many secondary effects of liver disease on distant organs are well known, and the eye is possibly affected in a manner which has not been recognized. For instance, raised levels of bile in the blood result in pruritus, and excessive levels of ammonia result in hepatic coma (Sodeman, 1956). It is not known whether these or similar mechanisms affect the eyes. Furthermore, it seems probable that viral hepatitis may be transmitted via donor material obtained from a jaundiced patient who has died of this disease. It may also be inadvisable to use donor materials from jaundiced patients who have died of cancer, because of the possible viral aetiology of cancer and also because of the possibility that the donor material is contaminated by malignant cells.

On the other hand, a search of recent literature yields little evidence of ocular damage resulting from jaundice. The disease kernicterus is interesting in this regard (Lee and Hsia, 1959; Hsia, Allen, Gellis, and Diamond, 1952; Jelíu, Schmid, and Gellis, 1959). Excessive haemolysis in newborn infants results in jaundice with high serum levels of indirect bilirubin. When the serum level reaches the region of $20 \mathrm{mg}$. per cent., sufficient bilirubin crosses the immature blood-brain barrier to stain and damage the basal ganglia (Nelson, 1954). The eyes are apparently spared from any damage in kernicterus, which suggests either that the eyes are protected by a barrier to bilirubin or that they are not sensitive to bilirubin. It seems likely, therefore, that the eyes from uncomplicated cases of jaundice are suitable sources of donor material.

\section{Conclusions}

The wide difference between the levels of bilirubin in serum and those in the ocular tissues and fluids indicates the presence of a barrier which restricts the entrance of bilirubin to the eyes. A very jaundiced eye from a person with a high serum bilirubin contains a very low concentration of bilirubin in spite of its bright yellow colour. The small amount of bilirubin which is actually present is not likely to be toxic to the eye. This is supported by the lack of organic and functional damage encountered in the eyes of jaundiced persons. The direct bilirubin in ocular tissues is water-soluble and washes out easily. Eyes from patients with obstructive jaundice appear, therefore, to be satisfactory sources of donor corneae and donor vitreous.

\section{REFERENCES}

Berman, L. B., Lapham, L. W., and Pastore, E. (1954). J. Lab. clin. Med., 44, 273.

Cantarow, A., and Trumper, M. (1955). "Clinical Biochemistry", 5th ed., pp. 525, 637. Saunders, Philadelphia.

CARTER, R. E., and MCGANN, C. J. (1959). Clin. Chem., 5, 106.

DUKE-ELDER, S. (1940). "Text-book of Ophthalmology", vol. III, pp. 2388, 2780. Kimpton, London. 
Duncan, G. G. (1959). “Diseases of Metabolism”, 4th ed., p. 380. Saunders, Philadelphia. EDWARDS, G. K., and Locke, J. C. (1960). Amer. J. Ophthal., 50, 108.

HARTSHORNE, I. (1934). Ibid., 17, 945.

Hsia, D. Y. Y., Allen, F. H., Gellis, S. S., and Diamond, L. K. (1952). New Engl. J. Med., 247, 668 .

Jelfu, G., SCHMid, R., and Gellis, S. S. (1959). Pediatrics, 23, 92.

LEE, T. C., and HSIA, D. Y. Y. (1959). J. Lab. clin. Med., 54, 512.

Malloy, H. T., and Evelyn, K. A. (1937). J. biol. Chem., 119, 481.

Naumann, H. N., and Young, J. M. (1960). Proc. Soc. exp. Biol. (N.Y.), 105, 70.

Nelson, W. E. (1954). "Text-book of Pediatrics", 6th ed., p. 986. Saunders, Philadelphia.

RobBins, S. L. (1957). " "Text-book of Pathology", pp. 212, 428. Saunders, Philadelphia.

SHERLOCK, S. (1958). "Diseases of the Liver and Biliary System”, 2nd ed., pp. 246, 358. Blackwell, Oxford.

Sodeman, W. A. (1956). “Pathologic Physiology”, 2nd ed., p. 657. Saunders, Philadelphia. 